\title{
Calcific Aortic Stenosis and Congenital Bicuspid Aortic Valves
}

\author{
MAURICE CAMPBELL \\ From the Cardiac Department, Guy's Hospital, London S.E.1, and The Institute of Cardiology, London W.I
}

Most cases of aortic stenosis are congenital, rheumatic, or calcific. For a long time only isolated cases were reported as congenital and some thought that nearly all were rheumatic, the sclerotic and calcific changes being secondary to earlier infection. This paper is concerned mainly with the clinical evidence about the nature of calcific aortic stenosis, with the frequency of sudden deaths in all forms of aortic stenosis, and with the incidence of congenital bicuspid aortic valves and the part they play in producing aortic stenosis.

After a few early cases and views have been mentioned, 60 cases of lone calcific aortic stenosis from Dr. Keith Simpson's necropsy records are analysed. The clinical evidence that bicuspid aortic valves become thickened and rigid at an early age and become calcified earlier than other valves is then reviewed on the basis of my own cases, some unpublished evidence kindly put at my disposal by Dr. Ariela Pomerance, and other published papers.

\section{SOME EARLy CASES AND VIEWS}

"A Parisian tailor, not yet old, having dined and left his house had walked hardly 40 paces when he suddenly fell to the ground and expired. His body was opened and no disease was found except that the three semilunar cusps leading to the aorta were bony" (Bonet, 1679, translated by White, 1951).

Lloyd (1847) reported two cases. One was a man, aged 23, who had good health till the last 8 months of his life when dyspnoea, attacks of sternal pain, and finally oedema of the ankles developed. He had long-standing aortic stenosis and his heart weighed $680 \mathrm{~g}$. Another man, aged 52, died suddenly during intercourse, having had some bronchitis for 7 years. The aortic orifice hardly admitted a probe, the valves being extremely ossified: the mitral orifice also was surrounded by a ring of bone.

Received December 20, 1967.
The Transactions of the Pathological Society contain many such accounts, including one by Peacock (1868). These three cases illustrate some common aspects of aortic stenosis.

Peacock $(1853,1865)$ thought that bicuspid aortic valves were likely to become inflamed and thickened and later osseous so that there was increasing stenosis and regurgitation. He reported among others three such cases: a man, aged 40, in whom the valves were not very irregular and the heart weighed 411 g.; a man, aged 45, with very severe stenosis and bony valves (heart weight, $567 \mathrm{~g}$.); and a boy, aged 18 , with stenosis and more regurgitation and a heart weighing $794 \mathrm{~g}$.

Several quotations that express Peacock's views clearly were given by Smith and Matthews (1955), and an earlier one from Paget (1844) saying that bicuspid valves were likely to become diseased. Clearly Peacock saw many examples and thought that bicuspid aortic valves were a not uncommon cause of aortic stenosis. It is strange how little attention was paid to this view for nearly a hundred years.

Wilks and Moxon (1875) wrote, "This petrifaction is the most frequent cause of simple aortic obstruction. The earthy concretions grow... until they are converted into immovable nodular masses of stone, with the orifice of the aorta reduced to a little chink. ... Such examples you may sometimes meet as causes of sudden death of halelooking old men who never had dropsy."

Osler (1886) emphasized the frequency of bicuspid aortic valves and how often they were attacked by bacterial endocarditis, a view that has been widely accepted, unlike that of Peacock. He put forward some evidence that they were true malformations and not due to foetal endocarditis. He found 18 examples in 800 necropsies, at least 4 times as many as are usually found. Only 3 died from unconnected causes, 6 dying from bacterial endocarditis, 6 
from congestive heart failure, 2 suddenly, and 1 from rupture of an intracranial aneurysm.

No reason was found for the two sudden deathsin a woman of 25 , in whom heart disease had been diagnosed for some years, and in a blacksmith, aged 45. Nor is it obvious why many others died with hypertrophied left ventricles and heart failure, for at several necropsies Osler demonstrated the absence of aortic regurgitation and did not mention aortic stenosis. Is it possible that he did not speak of aortic stenosis because of the fairly long opening, the obstruction being due to the thickening and rigidity of the cusps? Lewis (1933) said that for some time neither he, nor Mackenzie, nor Osler had diagnosed coarctation in his Case 3, a man with high blood pressure who had interested them all greatly.

Congenital aortic stenosis was not widely recognized for a long time, though the last-mentioned boy of Peacock, aged 18, and the first case of Lloyd, aged 23, almost certainly had this. The recognition that many cases of aortic stenosis in children and young and middle-aged adults were congenital owes much to Gallavardin $(1909,1921,1936)$. He emphasized the frequency of a type of aortic stenosis that was not rheumatic "qui se caractérise par sa tendence particulière à réalizer le rétrécissement aortique pur et que cette cause doit-être recherché en dehors des atteintes rhumatismales franches ou frustes". He described 50 cases, excluding all those over 50 years. Nearly four-fifths were male. Though one-third had an aortic diastolic murmur, it was not loud and the pulse was not water-hammer. He did not accept this type as a true malformation and thought an endocarditis of unknown origin in foetal life a more likely cause. The last paper I have found supporting this view is that of Farber and Hubbard (1933) who added 4 cases supposed to be of this type to 10 others reported previously.
Gordon, as early as 1922, reporting a case of valvar stenosis, "ventured to suggest it is of congenital origin and that the whole group (i.e. the first 8 cases of Gallavardin, 1909) has a similar origin". Grishman, Steinberg, and Sussman (1947) reported 23 cases of their own. Campbell and Kauntze (1953) reported 40 cases and labelled them firmly as congenital though many were in their third and fourth decades. The natural history has been fully discussed by Campbell (1968).

\section{DR. Simpson's 60 NeCROPsies OF LONE AORTIC STENOSIS}

I am indebted to Dr. Keith Simpson for letting me study his well-indexed records of coroner's necropsies. All cases indexed as valvular disease of the heart, starting in 1955, were analysed until I had 100 with a rheumatic aetiology, and this happened to give me 50 others. Together, they formed 2.2 per cent of all the necropsies carried out in about 6 years. The 150 cases are shown in Table $I$.

Rheumatic meant apparent rheumatic disease of the mitral valve, with or without aortic stenosis, so a few cases of sole rheumatic aortic stenosis may have been included in the developmental group. The 7 syphilitic cases were all men over 60 with large hearts (mean weight 565 g.). This group would have been much larger 30 years ago. Simpson in 1947 found they then formed 21 per cent, instead of the present 7 per cent of all the valvular disease. Valvular disease itself was about 10 per cent of all the cardiovascular and cerebrovascular causes.

Developmental cases included those without evidence of an infective cause, some with congenital aortic stenosis, and a much larger number where the stenosis had developed from increasing rigidity and

TABLE I

VALVULAR DISEASE OF THE HEART IN CORONER'S NECROPSIES

\begin{tabular}{|c|c|c|c|}
\hline & \multicolumn{2}{|c|}{150 consecutive cases } & \multirow{2}{*}{$\begin{array}{c}\text { Final } \\
\text { No. of cases }\end{array}$} \\
\hline & No. of cases & Percentage & \\
\hline $\begin{array}{l}\text { Developmental aortic stenosis } \\
\text { (a) in adults } \\
\text { (b) in children } \\
\text { Other malformations of heart } \\
\text { Syphilitic aortic regurgitation } \\
\text { All rheumatic disease }\end{array}$ & $\begin{array}{r}38 \\
2 \\
3 \\
7 \\
100\end{array}$ & $\begin{array}{r}25 \cdot 3 \\
1 \cdot 3 \\
2 \\
4 \cdot 7 \\
66 \cdot 7\end{array}$ & $\begin{array}{c}60 \\
2 \\
4 \\
\text { No change }\end{array}$ \\
\hline $\begin{array}{l}\text { Rheumatic aortic and mitral disease } \\
\text { (a) mainly aortic stenosis } \\
\text { (b) aortic stenosis less important } \\
\text { (c) aortic and mitral regurgitation } \\
\text { Mitral stenosis and/or regurgitation only }\end{array}$ & \multicolumn{2}{|c|}{$\begin{array}{l}20 \star \\
15^{\star} \\
8 \star \\
57^{\star}\end{array}$} & \\
\hline
\end{tabular}

$\star$ Number of cases and percentage of the rheumatic group. 
TABLE II PROBABLE AETIOLOGY OF 60 CASES WITH LONE CALCIFIC AORTIC STENOSIS

\begin{tabular}{c|c|c|c}
\hline & No. of cases & $\begin{array}{c}\text { With probable congenital } \\
\text { aortic stenosis }\end{array}$ & $\begin{array}{c}\text { With aortic stenosis that } \\
\text { had probably developed }\end{array}$ \\
\hline $\begin{array}{c}\text { With bicuspid aortic valves } \\
\text { With subaortic stenosis also }\end{array}$ & $\begin{array}{c}4 \\
47\end{array}$ & $2+1 ?$ & $5+1 ?$ \\
With tricuspid aortic valves & 2 & 2 \\
\hline Total & 60 & $3+2 ?$ & 42 \\
\hline
\end{tabular}

* This must include some calcified rheumatic cases, but those with rheumatic mitral disease also are excluded.

calcification of valves that had been healthy, generally tricuspid but sometimes bicuspid. My analysis was continued until the 38 adults with lone aortic stenosis had been increased to 60 , and these are the main subject of study. In addition to some of these adults having congenital aortic stenosis, there were 6 others with cardiac malformations.

Other Cardiac Malformations. There were 2 boys, one with subaortic stenosis and the other with slight aortic valve stenosis and severe coarctation which led to his death from rupture of the aorta. There were 3 interesting examples of pulmonary stenosis leading to sudden death in adults, and the sixth had an unusual calcified malformation of the mitral valve.

Lone Aortic Stenosis. Only 1 of these 60 subjects was under 40 and 90 per cent were over 50 years. The aortic valve was thought to be calcified in all and several may have had slight, and a few moderate, aortic regurgitation. Nine of the $60(15 \%)$ were reported as having bicuspid aortic valves and this was a minimal figure, since the term was used only when there was no sign of a spur on either valve.

Among these 9 the aortic stenosis was almost certainly congenital in 2 because it had been recognized when they were only 27 : both died suddenly, one at 33 when watching television and the other at 45 in the street. Another 5 (all between 67 and 79) seem much more likely to have had congenital bicuspid valves that had become calcified and stenosed, because few with congenital aortic stenosis live to these ages. The last 2, aged 50 and 56, are more difficult to place, and I have assumed that one belonged to each of the above-mentioned groups (Table II).

There were 4 men, aged from 53 to 72 , who had subaortic as well as valvar stenosis. Of these, 2 in their 50s with a history extending back some years were probably congenital, but in the older 2 both changes seem more likely to have been degenerative.

Most, perhaps all, of the other 47 cases had tricuspid valves. Of these, 3 aged between 41 and
46, with histories of their stenosis back into their 30 s, must have had congenital aortic stenosis; and I have assumed that 2 of the 4 , aged between 51 and 54 with histories known to go back at least to their 40s, also had congenital aortic stenosis. In the other 2, there was no known history and I have assumed that in them, and the remaining 40 , the stenosis was due to calcification of tricuspid valves that had been normal.

These conclusions are summarized in Table II. Of the 60 cases, $10(17 \%)$ had congenital aortic stenosis and another $6(10 \%)$ at least had congenital bicuspid aortic valves that had become calcified and stenosed. Most of the other $44(73 \%)$ seem to have had calcification, with or without Mönckeberg's sclerosis, of tricuspid valves that had been normal. A few of them would probably be moved to the rheumatic and congenital groups with more detailed examination of the aortic valve and more knowledge of the clinical history. Keith Simpson and I both realize the imperfection of this retrospective method. It is only the excellence of his notes and his care in getting a history where possible that has made my conclusions possible. I hope it will not be long before a more complete study is carried out, since the field is a valuable one for research.

Omitting the cases that were probably congenital, it seems that among those with calcific aortic stenosis, there is 1 case with a bicuspid valve for each 7 with tricuspid valves. This is a striking confirmation of Peacock's view that bicuspid valves are an important cause of aortic stenosis.

All Cases with Valvular Disease. The sex and age incidence is shown in Table III. As usual, the men form the majority $(67 \%)$ of those with lone aortic stenosis, but only 19 per cent of those with lone or predominant mitral disease.

There is not much difference in the age incidence among the various groups. The mean age is round about 60 , perhaps artificially high because older subjects are more likely to live alone and so to be without a doctor when they die. 
TABLE III

AGE AND SEX INCIDENCE OF SUBJECTS WITH CORONER'S NECROPSIES WITH VALVULAR DISEASE

\begin{tabular}{|c|c|c|c|c|c|c|c|c|c|}
\hline \multirow[b]{2}{*}{, } & \multirow{2}{*}{$\begin{array}{l}\text { No. of } \\
\text { cases }\end{array}$} & \multicolumn{7}{|c|}{ Percentages } & \multirow{2}{*}{$\begin{array}{c}\text { Mean } \\
\text { age }\end{array}$} \\
\hline & & Of men & $\begin{array}{l}20 \\
\text { to } \\
29\end{array}$ & $\begin{array}{l}30 \\
\text { to } \\
39\end{array}$ & $\begin{array}{l}40 \\
\text { to } \\
49\end{array}$ & $\begin{array}{l}50 \\
\text { to } \\
59\end{array}$ & $\begin{array}{l}60 \\
\text { to } \\
69\end{array}$ & $\begin{array}{l}70 \\
\text { and } \\
\text { over }\end{array}$ & \\
\hline $\begin{array}{l}\text { Lone aortic stenosis } \\
\text { Aortic and mitral disease. } \\
\text { Mitral stenosis and/or regurgitation only }\end{array}$ & $\begin{array}{l}60 \\
35 \\
57\end{array}$ & $\begin{array}{l}67 \\
31 \\
19\end{array}$ & $\begin{array}{l}0 \\
3 \\
4\end{array}$ & $\begin{array}{r}2 \\
6 \\
12\end{array}$ & $\begin{array}{r}8 \\
9 \\
19\end{array}$ & $\begin{array}{l}32 \\
39 \\
26\end{array}$ & $\begin{array}{l}33 \\
23 \\
20\end{array}$ & $\begin{array}{l}25 \\
20 \\
19\end{array}$ & $\begin{array}{l}62 \\
57 \\
56\end{array}$ \\
\hline
\end{tabular}

TABLE IV

HEART WEIGHT IN LONE AORTIC STENOSIS AND OTHER GROUPS

\begin{tabular}{|c|c|c|c|c|c|c|c|c|}
\hline & \multicolumn{8}{|c|}{ Heart weight (g.) } \\
\hline & $<400$ & $400-499$ & $500-599$ & $600-699$ & $700-799$ & $800-899$ & $900-999$ & $1000-1025$ \\
\hline \multirow[t]{3}{*}{ No. of cases } & 2 & 15 & 17 & 12 & 7 & 2 & 1 & 1 \\
\hline & \multirow{2}{*}{\multicolumn{2}{|c|}{$\begin{array}{l}\text { Calcific aortic } \\
\text { stenosis }\end{array}$}} & \multicolumn{4}{|c|}{ Rheumatic } & \multirow{2}{*}{\multicolumn{2}{|c|}{$\begin{array}{l}\text { Syphilitic aortic } \\
\text { regurgitation }\end{array}$}} \\
\hline & & & $\begin{array}{c}\text { Mainly } \\
\text { sten }\end{array}$ & $\begin{array}{l}\text { aortic } \\
\text { sis }\end{array}$ & $\begin{array}{r}\text { Aortic an } \\
\text { regurgi }\end{array}$ & $\begin{array}{l}\text { mitral } \\
\text { ation }\end{array}$ & & \\
\hline Mean weight (g.) & \multicolumn{2}{|c|}{587} & \multicolumn{2}{|c|}{$(652)^{\star}$} & \multicolumn{2}{|c|}{765} & \multicolumn{2}{|c|}{565} \\
\hline No. of cases & \multicolumn{2}{|c|}{57 of 60} & \multicolumn{2}{|c|}{10 of 20} & \multicolumn{2}{|c|}{7 of 8} & \multicolumn{2}{|c|}{4 of 7} \\
\hline
\end{tabular}

* Shown in brackets because the weight was recorded in only half of them.

As might be expected in a group with many sudden deaths, lone or predominant aortic stenosis formed a larger proportion of all valvular disease $(60$ of $150,40 \%$ ) than is found in most series.

The heart weights for all groups were fairly high. Table IV shows the distribution of weights for those with lone aortic stenosis and the mean weight of the groups where most of the heart weights were recorded. It was not often recorded in those with lone mitral disease, probably because the hearts looked smaller. The apparently heavier hearts of those with rheumatic aortic and slighter mitral stenosis may be because the weight was recorded in only half of them (probably the heavier half) while in the other groups it was recorded more often. Mitchell et al. (1954) found them lighter (577 g.) than in those with aortic disease only (669 g.).

Modes of Death. With such a wide variety it is hard to discuss this shortly. Among coroner's cases sudden deaths must be common. I cannot define the meaning of sudden precisely but if a patient collapsed at home and was dead before a doctor arrived, or in the street and died before reaching hospital, the death has been called sudden unless there were notes that this interval was long. I read the notes about the history before reading the diagnosis to decide if the death was sudden.

In those with sole aortic stenosis 44 of the 60
(73\%) died suddenly. More than half of them were known to have heart disease, often for several years, but there was no information about this in many others. Generally there was no obvious external cause and about equal numbers died when sitting or doing easy work at home (13), when walking or standing in the street or a shop (13), or when in bed at night (10). Only 5 died at work; none were doing anything strenuous and one was sitting in the driving seat of his stationary lorry. Only 3 died when doing something that may have been rather strenuous, two when pushing motor bikes that had broken down and one just after pushing a wheel-barrow to his allotment.

The other 16 died with left-sided or congestive heart failure, 12 gradually and 4 rather more suddenly.

In the 57 with mitral disease only, the sudden deaths were much less $(21 \%)$ but more than I expected. In 2 a ball-thrombus had blocked the mitral valve, and in 4 death was probably due to ventricular fibrillation or some other arrhythmia, as in a woman of 41 who was being driven in her car to buy a new house. Presumably these were also the mechanisms in many of the sudden deaths in aortic stenosis. In 3 there was a sudden collapse when talking to friends or at work, and death followed quickly. The last 3 died with pulmonary oedema probably within 15 minutes. If these last 
were not sudden enough to include, the proportion would be reduced from 21 to 16 per cent.

More often those with pulmonary oedema died a few hours.after they had reached hospital (9 cases). Another 8 died after emboli but not suddenly enough to include in that group, and 6 soon after valvotomy. The commonest cause was congestive heart failure (20 cases), though in 5 of these the moment of death was unexpected.

The 43 cases with rheumatic aortic stenosis and mitral disease occupied an intermediate position with 46 per cent of sudden deaths.

\section{Bicuspid Aortic Valves}

Incidence. These occur in 4 per 1000 of all births, the most common malformation of the heart. Their liability to become stenosed was recognized much later than their liability to bacterial endocarditis and calcification.

Lewis and Grant (1923) wrote about the histological signs that differentiate between bicuspid valves that are congenital and those that have been caused by inflammation, and their high incidence, 26 per cent, in their series of cases of bacterial endocarditis. They thought that 23 per cent of adults with bicuspid valves developed endocarditis at some time.

Wauchope (1928) found the aortic valves were bicuspid in $52(0.5 \%)$ of 9966 necropsies at the London Hospital. They were fairly evenly distributed between the first seven decades. Her 13 cases with endocarditis ( 6 bacterial) came to hospital because of this infection of the valves, so are omitted. The other 39 (9 with pneumonia, 8 with peritonitis, 6 with other infections, 5 with accidents, and 2 with cancer, etc.) cannot have come to hospital because their valves were bicuspid. They, therefore, give a true measure of the incidence, 0.39 per cent. Bacon and Matthews (1959), without this allowance for some selection in hospital necropsies, found an incidence of 0.5 per cent (range, 0.2 to $0 \cdot 8$ ) in 28,431 reported series of necropsies. Among these patients with bicuspid valves, 78 per cent were male and only 22 per cent were female.

Congenital aortic bicuspid valves are much more common in lone aortic stenosis, from 15 to about 36 per cent (see later). They are even more common in congenital aortic stenosis, about 57 per cent (Campbell, see Table VI; Baker and Somerville, 1964; Hohn et al., 1965), and most common (74\%) in aortic stenosis associated with coarctation of the aorta (Smith and Matthews, 1955). Donald Ross (1967, personal communication) found that the valve was bicuspid in 82 of the last 100 where he had drawn a picture.
Thickening and Calcification. Osler (1886) found that bicuspid valves were thickened in every patient over 25 years. Wauchope found they were fibrous, atheromatous, or calcified in 29 per cent of her cases and in all over 40 , but even after 60 calcification was noted in only 4 of 7 cases.

Bacon and Matthews (1959) made a useful survey in nine London museums of the 48 specimens of bicuspid aortic valves where the age of the patient was recorded. They based their conclusions on a conservative estimate that 28 of these specimens were congenital. In those under 40 years, only 4 of the 10 bicuspid valves were thickened (less so than in older subjects) and none was calcified. In those aged 40-49 years, 3 of the 6 were thickened and calcified and 3 were not. In those over 50 all 12 were thickened, and all but 2 , both aged 55 , were calcified. A. Pomerance (1967, personal communication) found that none of her 4 bicuspid valves in those under 50 was calcified, but 7 of her 20 examples over 50 years were. I am greatly indebted to her for letting me have her figures, shown in Table $\mathrm{V}$.

In summary, bicuspid aortic valves often become thickened by 30 , generally by 40 , and always by 50 years of age. They are rarely, if ever, calcified by 40 , but often (perhaps about $25 \%$ ) between 40 and 49 , and in more than half $(60 \%)$ of those aged 50 or more; even after 70 by no means all are calcified. This applies to bicuspid valves that were thought not to have produced significant aortic stenosis, but when they are rigid and calcified there must, I think, be enough obstruction to cause some stenosis. The approximate percentages with calcification at different ages are shown in the Figure, and compared with normal aortic valves with three cusps. The latter is based on the 805 cases examined and reported by Pomerance (1967). Except for these, the other curves must be taken as rough ranges on the available evidence. To the left, the percentages with calcification among cases with acquired and congenital aortic stenosis are shown, the incidence of calcification increasing from right to left of the figure.

Calcification of Tricuspid Aortic Valves. Pomerance (1967) found that atheroma of the anterior mitral cusp and calcification of the mitral valve ring and of the aortic valve cusps were the three main changes that were directly associated with ageing. In both sexes 5 per cent of aortic valves showed some calcification by 55 years and after this the proportion increased nearly 1 per cent each year to 30 per cent at 85 years. Before 45 , calcification was absent in women but present in about 4 per cent of 


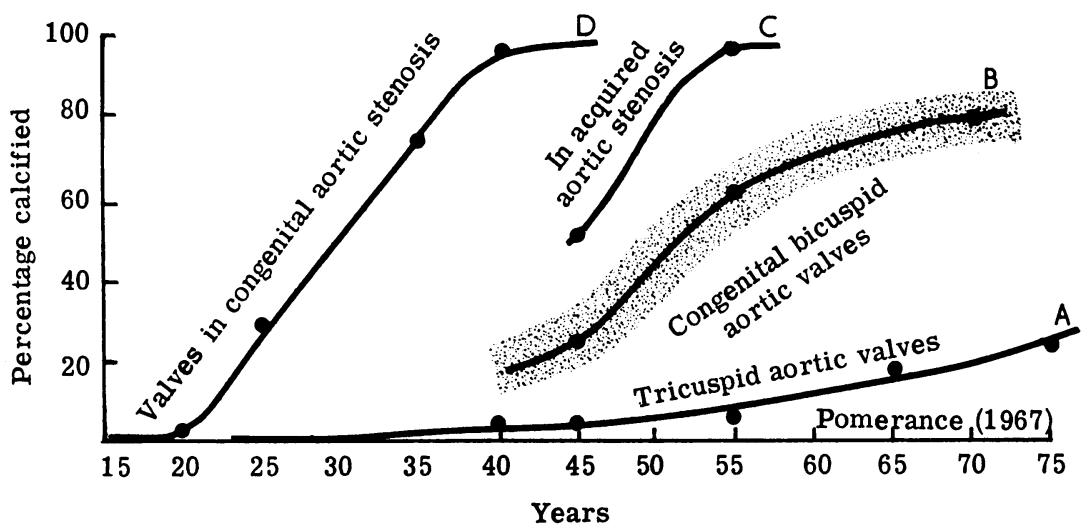

FIG.-Incidence of calcification with increasing age. (A) In normal aortic valves with three cusps (based on 805 cases of Pomerance (1967)). (B) In congenital bicuspid aortic valves. The shaded area defines the probable limits of accuracy. (C) In the aortic valves of acquired aortic stenosis. (B) and (C) are based mainly on Wauchope (1928), Bacon and Matthews (1959), and A. Pomerance (personal communication). (D) In the valves of congenital aortic stenosis. Based mainly on Campbell (Table VI) and Baker and Somerville (1964).

men (this might be associated with the much higher male incidence of bicuspid aortic valves).

This suggests that some bicuspid aortic valves become calcified 15 years earlier than tricuspid valves and that by 60 eight times as many are calcified (see Figure).

\section{Bicuspid Aortic Valves and Aortic Stenosis}

McGinn and White (1934) alone among the many who wrote about aortic stenosis at this time seem to have recorded the number with bicuspid valves. They found 30 examples in 123 cases of aortic stenosis (50 with mitral stenosis also) among 6800 necropsies. Their data about these 30 cases were not emphasized and no deductions were made then or, so far as I know, later about them.

From their table, I have co-ordinated the following findings. The aortic valves were bicuspid in $26 \%$ (22) of the 82 with calcified valves; $60 \%$ were over 50 ;

in $22 \%$ (8) of the 37 with non-calcified valves; $11 \%$ were over 50 ;

in $8 \%$ (4) of the 50 with aortic and mitral stenosis; and in $36 \%$ (26) of the 73 with aortic stenosis only.

Thus, bicuspid aortic valves were equally common in the non-calcified valves, mainly in younger subjects, and in the calcified valves, mainly in older people. They were, however, more than four times as common in the patients with lone aortic stenosis as in the rheumatic ones with aortic and mitral stenosis.

This large proportion of bicuspid valves among the older patients with lone aortic stenosis suggests strongly that the stenosis had often been caused by calcification of congenital bicuspid valves. The relatively small number among the rheumatic cases suggests that not many had been caused by inflammatory changes, even though bicuspid valves may be more prone to rheumatic endocarditis, as they are to bacterial endocarditis.

Smith and Matthews (1955) found bicuspid aortic valves in 20 of 27 cases, where aortic valve stenosis occurred with coarctation of the aorta. Only 1 (a man aged 45) of the 6 with adequate microscopical examination had evidence that 2 of the original 3 cusps had become fused by inflammatory changes. The other 5 and probably 8 of the remaining 14 had congenital bicuspid valves. Thus, 13 of the 20 were congenital and only 1 was shown not to be, which suggests that these valves are likely to become stenosed. They thought that the stenosis had generally developed on congenital bicuspid valves. In 2 of their personal cases, aged 43 and 55, this was almost certainly so but in 2 , aged 18 , the stenosis may have been congenital.

Campbell and Baylis (1956) did not discuss the cause of the aortic stenosis in 6 of their 180 cases with coarctation. In their Case 24, aged 31, there were bicuspid aortic valves and the stenosis had probably developed as a result and most likely this was so in 2 others. It is less certain in 2 aged 21 and 23 where there may have been congenital aortic stenosis and in the sixth (Case 1) it was almost certainly rheumatic. Another example has been seen since. Sir John Parkinson had diagnosed coarctation only with a blood pressure of $235 / 122 \mathrm{~mm}$. $\mathrm{Hg}$ in a woman aged 35 . When she was $58, \mathrm{I}$ found the blood pressure was only $155 / 100 \mathrm{~mm}$. $\mathrm{Hg}$ and as there were now striking signs of calcific 
TABLE V

DR. POMERANCE'S FIGURES FOR CALCIFICATION OF BICUSPID AND OTHER VALVES WITH OR WITHOUT AORTIC STENOSIS

\begin{tabular}{|c|c|c|c|c|c|c|c|c|c|c|}
\hline & \multicolumn{10}{|c|}{ Age (years) } \\
\hline & $20-29$ & $30-39$ & $40-49$ & $50-59$ & $60-69$ & 70-79 & $80-89$ & Male & Female & Total \\
\hline $\begin{array}{l}\text { With Stenosis } \\
\text { (1) Valve tricuspid or indeterminate } \\
\text { Rheumatic or inflammatory } \\
\text { Senile calcific or indeterminate } \\
\text { (2) Valve bicuspid } \\
\text { No. Stenosis } \\
\text { (3) Valve bicuspid }\end{array}$ & $\begin{array}{l}\bar{Z} \\
0 / 1\end{array}$ & $\begin{array}{l}\bar{z} \\
0 / 1 \\
0 / 2\end{array}$ & $\begin{array}{l}\frac{1 / 1^{\star}}{0 / 1} \\
0 / 1\end{array}$ & $\begin{array}{l}3 / 3 \\
3 / 4 \\
- \\
2 / 6\end{array}$ & $\begin{array}{l}4 / 4 \\
3 / 4 \\
3 / 3 \\
3 / 9\end{array}$ & $\begin{array}{l}1 / 1 \\
1 / 1 \\
6 / 6 \\
1 / 3\end{array}$ & $\begin{array}{c}3 / 3 \\
10 / 10 \\
3 / 3 \\
1 / 2\end{array}$ & $\begin{array}{r}6 \\
12 \\
13 \\
12\end{array}$ & $\begin{array}{r}6 \\
7 \\
1 \\
12\end{array}$ & $\begin{array}{l}12 \\
19 \\
14 \\
24\end{array}$ \\
\hline $\begin{array}{l}\text { All Bicuspid Valves } \\
\text { With or without aortic stenosis } \\
\text { Percentage Calcified Bicuspid and Tricuspid }\end{array}$ & $\underset{0}{0 / 1}$ & $\begin{array}{c}0 / 3 \\
0\end{array}$ & $\begin{array}{l}0 / 2 \\
33\end{array}$ & $\begin{array}{l}2 / 6 \\
61\end{array}$ & $\begin{array}{l}6 / 12 \\
65\end{array}$ & $\begin{array}{l}7 / 9 \\
82\end{array}$ & $\begin{array}{l}4 / 5 \\
94\end{array}$ & 25 & 13 & $38 t$ \\
\hline
\end{tabular}

* The figures on the left are the number calcified and the figures on the right are the total number.

+ Twenty-nine of these 38 bicuspid valves showed a raphe and 9 did not.

aortic stenosis it seems certain that this had developed in the previous 20 years, and probably on congenital bicuspid valves.

Bacon and Matthews (1959) found that 13 of their 28 museum specimens with bicuspid valves had also aortic stenosis: 11 of the 13 who were 50 and over, and 1 of the 5 between 40 and 49 years. Only 1 of 10 under 40 had aortic stenosis: he was only 18 and had also coarctation of the aorta, so probably his stenosis was congenital. The many cases over 50 years with aortic stenosis again suggest strongly that it has developed as the bicuspid valves became more rigid and calcified. They examined also all the museum specimens with aortic stenosis. Of the 50 without mitral stenosis, 18 had a bicuspid valve, 12 were uncertain, and 20 had a tricuspid valve. Of the 30 who had also mitral stenosis, all had a tricuspid valve.

Matthews and his collaborators in these two papers thought valve rigidity, rather than fusion of the cusps, was the major cause of the obstruction. They concluded that Peacock's views were correct and that "a congenital bicuspid aortic valve is liable to develop calcific degeneration earlier and more consistently than a normal valve and that these changes may lead to aortic stenosis". Further evidence to support this view has been produced. It is interesting that 36 per cent of cases of lone aortic stenosis, mostly calcific, had bicuspid aortic valves in two separate series (McGinn and White, 1934; Bacon and Matthews, 1959). Though this is more than the 15 per cent found in Keith Simpson's series (Table II) the incidence is clearly very high.

\section{Calcification of Valves in Aortic Stenosis}

Dr. Ariela Pomerance has with great kindness allowed me to have her findings about calcification of the valves in $\mathbf{4 5}$ subjects with aortic stenosis and in 24 others in whom the valve was bicuspid without obvious stenosis (Table V). When there was aortic stenosis the valve, whether tricuspid (31) or bicuspid (14), was calcified in 40 of the 42 aged 50 or more, in 1 of the 2 in their 40s, but not in the only 1 in his $30 \mathrm{~s}$. There were very few young patients in the series as the hospital had no thoracic surgical unit. Wood (1956) also thought that calcification of the aortic valves could nearly always be seen on radioscopy in those aged 50 or over.

Congenital Aortic Stenosis. Here calcification of the valve may be expected earlier since it has been exposed to turbulence and a raised blood pressure from birth or before. This is borne out by general experience. Baker and Somerville (1964) found the aortic valve calcified in all the 89 cases over. 40 who had aortic valvotomy and in 34 of the 63 who were $\mathbf{4 0}$ or under. They did not break down the latter group into decades, but have kindly informed me that there was only one patient under 20 with flecks of calcium in the myxomatous valve and that many in the third and nearly all in the fourth decade were calcified.

In my series of 69 cases (Table VI) the valve was nearly always uncalcified in the first two decades. There was only one exception, a man aged 18 (Fig. 1, Campbell and Kauntze, 1953) in whom 6 years later the calcification was confirmed at necropsy. The third and fourth decades are the time of change. In the third decade two-thirds are still uncalcified but nearly a third are calcified. In the fourth decade, more than two-thirds have become calcified, though nearly a third have not. In the fifth decade and later, all were calcified. The two series agree well, though where operation excluded the slighter cases and gave a better chance of finding slighter calcification than radioscopy, there was a rather larger proportion with calcification in the third and fourth decades. 
TABLE VI

AGE OF VALVE CALCIFICATION IN CONGENITAL AORTIC STENOSIS

\begin{tabular}{l|c|c|c|c|c|c|c|c}
\hline & \multicolumn{7}{c|}{ Age-groups } & Total \\
\cline { 2 - 8 } & $0-9$ & $10-19$ & $20-29$ & $30-39$ & $40-49$ & $50-59$ & 0 \\
\hline $\begin{array}{l}\text { Not calcified } \\
\text { Calcified }\end{array}$ & 18 & 15 & 10 & $5+0$ & $0+3$ & $0+1$ & $48+4$ \\
\hline
\end{tabular}

Note: The first (or only) figure in each age-group denotes the number with aortic stenosis that was congenital. Three cases that were uncalcified in the 3rd or 4th decade and calcified in the 4th or 5th are included twice, raising the total from 69 to 72 . Cases uncalcified in the 2nd decade and calcified later are shown only in the latter category.

The second figure in columns on the right of the Table denotes the number where the aorticstenosis may have been congenital or may have been caused later by bicuspid valves that became rigid (and generally calcified).

\section{Aortic Stenosis Caused by Rigid Bicuspid VALVES}

The difficulty in deciding whether the aortic stenosis was truly congenital in a patient of 30 or 40 years where there was no record that his murmur had been heard until a few years before, was one reason for writing this paper. Obviously it may be congenital and there may have been no occasion for any doctor to comment on his heart. Equally, he may have been without a murmur until normal bicuspid aortic valves became rigid enough to produce some stenosis and it is then a question of semantics whether he had congenital aortic stenosis.

These two groups have been distinguished in Table VI. The first (or only) figure in each agegroup denotes the number in whom the stenosis was certainly congenital, where the murmur had always been heard and noted before the patient was 20-in 84 per cent before he was 10 , and in 60 per cent when he was 5 years or younger.

The second figure in each age-group in the righthand columns of the table denotes those in whom the stenosis may be congenital or may have been caused by bicuspid aortic valves becoming increasingly rigid (and generally calcified). Here there was no history that the murmur had been heard before the age of 20 , though it may have been present from birth. Naturally these patients were older. In 14 of the 18 the aortic valve was calcified, but in 3 aged 40-49 and in 1 aged 53 no calcification could be seen on radioscopy. The last man had been rejected from the army when 20 because of a murmur but had no symptoms till he was over 50 . He was seen at 53 and again at 55 with congestive heart failure from which he died a year later. He was screened twice but I may have failed to see calcification on radioscopy.

Dr. Deuchar has given me a good example of this borderland between aortic stenosis and rigid, probably bicuspid, valves and will I hope be able to follow the subsequent changes. A boy of 12 had a loud aortic systolic murmur and thrill without other signs. He was thought to have aortic stenosis but catheterization showed no more than a borderline gradient of $10 \mathrm{~mm}$. $\mathrm{Hg}$.

There is other evidence of the gradual development of aortic stenosis without any obvious cause. Levine (1933) said he had seen many patients with no more than a systolic murmur who in the course of years had developed obvious aortic stenosis. Herrick (1933) agreed with this and added "after 20 or 30 years observation". In 1945, Levine wrote that he had followed many middle-aged patients with a systolic murmur only of moderate intensity long enough for them to develop clear signs of aortic stenosis.

Pyke and Symons (1951) found calcification of the aortic valve in 11 of 400 men over 60 years of age. All had a basal systolic murmur, loud in all but one, yet nearly always with evidence that it had not been present in middle age. Thus, 3 who had been without a murmur at annual examinations for 12 , 31 , and 37 years were found to have developed them at 65,54 , and 66 years, respectively; 3 others had served in the army or police for an average of 12 years without any comment on their hearts about 30 years before; and $3 \mathrm{had}$ records of their hearts having been passed as normal earlier.

Many doctors must have seen elderly patients with striking signs of aortic stenosis but with nothing in their history to suggest how this had arisen. I had a folder with notes of about 20 patients, mostly men near 60 or over, with unequivocal signs of calcific aortic stenosis and generally with little or no evidence of aortic regurgitation. None had any clinical evidence of mitral stenosis or a history of rheumatism or anything else likely to have caused the aortic stenosis. Unfortunately the folder is lost so I cannot give more details. I am not suggesting that all these patients had bicuspid aortic valves, since tricuspid valves can become calcified and stenosed, but probably several of the younger ones among them had. 
TABLE VII

SEX AND AGE INCIDENCE IN CALCIFIC AND PREDOMINANT AORTIC STENOSIS

\begin{tabular}{|c|c|c|c|c|c|c|c|}
\hline & \multicolumn{3}{|c|}{ No. of cases } & \multicolumn{2}{|c|}{ Age (years) } & \multicolumn{2}{|c|}{ Causes of death } \\
\hline & All & $\mathbf{M}$ & $\mathbf{F}$ & $\begin{array}{l}40 \\
\text { and } \\
\text { over }\end{array}$ & $\begin{array}{c}\text { Under } \\
\text { Und }\end{array}$ & $\begin{array}{c}\text { Congestive } \\
\text { heart } \\
\text { failure }\end{array}$ & Sudden \\
\hline $\begin{array}{l}\text { Cabot (1926) } \\
\text { Christian (1931) } \\
\text { Margolis et al. (1931) }\end{array}$ & $\begin{array}{l}28 \\
21 \\
42\end{array}$ & $\begin{array}{l}25 \\
15 \\
34\end{array}$ & \multicolumn{3}{|c|}{$\begin{array}{l}\text { Calcific Aortic Stenosis } \\
22 \\
\begin{array}{|c|c}16 & 6 \\
39 & 5 \\
& 3\end{array}\end{array}$} & \multicolumn{2}{|c|}{$\stackrel{9}{9} \stackrel{5}{\text { Mostly non-cardiac }}$} \\
\hline Total & 91 & 74 & 17 & 77 & 14 & & \\
\hline $\begin{array}{l}\text { Willius (1927) } \\
\text { Campbell and Shackle (1933) } \\
\text { Gibbs (1935) } \\
\text { Contratto and Levine (1937) } \\
\text { Mitchell et al. (1954) } \\
\text { Oleson and Warburg (1958) }\end{array}$ & $\begin{array}{r}96 \\
54 \\
27 \\
180 \\
93 \\
39\end{array}$ & $\begin{array}{r}80 \\
41 \\
18 \\
108 \\
62 \\
28\end{array}$ & $\begin{array}{r}16 \\
13 \\
9 \\
72 \\
31 \\
11\end{array}$ & $\begin{array}{c}\text { uinant } \\
61 \\
39 \\
21 \\
141 \\
\star \\
34\end{array}$ & $\begin{array}{c}\text { cenosis } \\
35 \\
15 \\
6 \\
39 \\
\star \\
5\end{array}$ & $\begin{array}{c}48 \text { Mos } \\
\text { Mostly conge } \\
44 \\
39 \\
29\end{array}$ & $\begin{array}{l}\text { ing } \\
\text { heart failure } \\
9+ \\
19+ \\
7\end{array}$ \\
\hline Total & 489 & 337 & 152 & 296 & 100 & 169 & 48 \\
\hline
\end{tabular}

* Mean age of these was 56 years.

$t$ In these two series the sudden deaths and those from bacterial endocarditis were about the same.

\section{Calcific or Predominant Stenosis}

The many papers on these types of aortic stenosis in that decade after 1926 when Cabot published his classic Facts on the Heart seem worth a short discussion, though they do not help us much as regards the aetiology.

Calcific aortic stenosis aroused a good deal of interest after Cabot (1926) described 28 such cases. Christian (1931) reported 21 examples with an average heart weight of $680 \mathrm{~g}$. (range 505-1045). He emphasized the many years that had passed without symptoms and the short life after these started. Margolis, Ziellessen, and Barnes (1931) added 42 more. One-third had died from non-cardiac causes and often the diagnosis had not been made till late in life. Congestive heart failure was the commonest cause of death, but 5 died suddenly.

In these three series 77 of the 91 subjects (85\%) were 40 or over and $74(81 \%)$ were men (Table VII). The other series, also shown in Table VII, with predominant aortic stenosis give a rather wider view of aortic stenosis, though they were not very different, 75 instead of 85 per cent being 40 or over and 69 instead of 81 per cent being men. There is more information about the causes of death. Congestive heart failure was the commonest cause (160 cases), but sudden death (43) accounted for about a quarter of this and bacterial endocarditis for about the same.

Predominant aortic stenosis was the diagnosis in most of the second series of cases. Willius (1927) traced 76 of 96 patients he had seen and $56(74 \%)$ had died in less than two years. Contratto and Levine (1937) reported 180 cases without mitral stenosis and thought the angina (in 25\%) was caused by the aortic stenosis as the coronary arteries were generally healthy. Death generally followed less than 5 years after significant symptoms. Calcification was not noted under 45 years of age.

Mitchell et al. (1954) found calcification in 62 per cent of their 29 patients with pure aortic stenosis, who died at a mean age of 65 with a mean heart weight of $636 \mathrm{~g} . ;$ and in 50 per cent of the 63 with aortic regurgitation as well as stenosis, who died at a mean age of 49 with a mean heart weight of $686 \mathrm{~g}$.

Oleson and Warburg (1958) followed 39 of 42 patients with lone aortic stenosis till their deaths. The mean duration of symptoms had been 6 years, but only 5 years after angina (found in $52 \%$ ) and only 3 years after syncope (in $22 \%$ ).

Aetiology. Cabot (1926) thought his cases of calcific aortic stenosis were not rheumatic, though some gave a rheumatic history and there was relative freedom from atheroma of the aorta. Most subsequent writers thought all or most were rheumatic though such a history was obtained in less than half (Willius, 1927; Christian, 1931; McGinn and White, 1934) or even in as few as 15 per cent (Mitchell et al., 1954). They seem to have been unduly influenced by the dogmatic view that all cases of valvular disease, except syphilitic aortic regurgitation, were rheumatic. Even in 1958, Wood divided his 250 cases of aortic stenosis into congenital $(22 \%)$ and rheumatic, though he wrote that, if so, one-quarter of all those with rheumatic heart disease must develop aortic stenosis (Wood, 1956).

They were supported by the histological evidence of Clawson, Noble, and Lufkin (1938) and later by Karsner and Koletsky (1947), though Hall and 
Anderson (1943) had shown that their "rheumatic" stigmata were found in 90 per cent of routine heart examinations.

Margolis et al. (1931), on the other hand, rightly thought the original cause was hidden by the subsequent degeneration and calcification, and would be discovered only by clinical studies conducted over many years in earlier life.

Campbell and Shackle (1933) found that 20 of their 54 personal cases with lone aortic stenosis were sclerotic and 34 rheumatic. Most of the former but only 5 of the rheumatic had stenosis without regurgitation. Gibbs (1935) thought 12 of his 27 necropsy cases were sclerotic (all over 40 with a mean age of 64); and 15 rheumatic, all but 3 with mitral stenosis also ( 9 over 40 with a lower mean age of 50 years). The aortic valve was calcified in all but 1 of the 21 over 40 and in 1, aged 34 .

\section{SUMmaRY AND CONClUSIONS}

From Dr. Keith Simpson's records of his coroner's necropsies, 60 consecutive cases of lone aortic stenosis without evidence of past rheumatic infection of the mitral valve have been examined. The stenosis was probably congenital in 10 and acquired in 50: here "acquired" almost certainly means by thickening and calcification rather than by rheumatic or other infection.

The aortic valve was bicuspid in 6 of these 50 cases. This high incidence, nearly 20 times what would be expected by chance even in men, shows that bicuspid valves are specially prone to develop aortic stenosis. No doubt many of the others are due to calcification of ordinary tricuspid valves. Pomerance (1967) has shown that 5 per cent of these are calcified at 55 years, and the number increases by nearly 1 per cent each year to 30 per cent at 85 years.

Naturally, sudden deaths were common in a series such as Simpson's; in nearly three-quarters of those with lone aortic stenosis, but in only one-fifth of those with lone mitral disease. In many reported series with lone aortic stenosis, sudden deaths account for about one-sixth of the total. In my series of congenital aortic stenosis a third of all the deaths and half of those in children were sudden.

The aortic valves are bicuspid in 4 of every 1000 births. They are thus the most common malformation of the heart. They are much more common in male subjects who form four-fifths of the total number.

Bicuspid aortic valves are generally thickened before 40 and always by 50 years. The work of Wauchope (1928), Bacon and Matthews (1959), and Table V, some unpublished data that Dr. Ariela Pomerance has kindly put at my disposal, show that about one-quarter have become calcified in the fifth decade and about half in those over 50 years.

Bicuspid valves are common in lone aortic stenosis (from 15 to $35 \%$ ) and most common in the aortic stenosis found with coarctation of the aorta (over $70 \%$, Smith and Matthews, 1955). These high incidences confirm the view of Peacock (1853) that bicuspid valves are likely to become thickened and osseous so that there is increasing aortic stenosis. The view of Osler (1886) that they are very liable to bacterial endocarditis is generally accepted.

Bicuspid valves are very common with congenital aortic stenosis, about 50 per cent. Here they become calcified earlier but rarely before 20 . years. Nearly one-third become calcified by 30 , more than two-thirds by 40 , and nearly all soon after this.

When a patient is not seen till early middle-age and is found to have lone aortic stenosis, it may not be possible to decide if this is congenital or if congenital bicuspid valves have caused the aortic stenosis. Many more subjects will have to be followed for years to settle this. In my series 69 patients were thought to have congenital aortic stenosis and 18 might have belonged to either group.

It is a pleasure to express my thanks to Dr. Keith Simpson for allowing me to study his well-kept reports of his coroner's necropsies; to Dr. Ariela Pomerance for letting me have her findings about calcification in aortic stenosis and in lone bicuspid aortic valves; and to many colleagues with whom I have worked on aortic stenosis.

\section{REFERENCES}

Bacon, A. P. C., and Matthews, M. B. (1959). Congenital bicuspid aortic valves and the aetiology of isolated valvular stenosis. Quart. F. Med., 28, 545.

Baker, C., and Somerville, J. (1964). Results of surgical treatment of aortic stenosis. Brit. med. F., 1, 197.

Bonet, T. (1679). Translated by and quoted from White (1951).

Cabot, R. S. (1926). Facts on the Heart. W. B. Saunders, Philadelphia.

Campbell, M. (1968). The natural history of congenital aortic stenosis. Brit. Heart $\mathcal{F}$., 30, 514.

- and Baylis, J. H. (1956). The course and prognosis of coarctation of the aorta. Brit. Heart f., 18, 475.

- and Kauntze, R. (1953). Congenital aortic valvular stenosis. Brit. Heart $\mathcal{F}$., 15, 179.

- and Shackle, J. W. (1933). Disease of the aortic valves. Guy's Hosp. Rep., 83, 168.

Christian, H. A. (1931). Aortic stenosis with calcification of the cusps. F. Amer. med. Ass., 97, 158.

Clawson, B. J., Noble, J. F., and Lufkin, N. H. (1938). The calcified nodular deformity of the aortic valve. Amer. Heart $\mathcal{F} ., 15,58$.

Contratto, A. W., and Levine, S. A. (1937). Aortic stenosis with special reference to angina pectoris and syncope. Ann. intern. Med., 10, 1636.

Farber, S., and Hubbard, J. (1933). Foetal endomyocarditis: intrauterine infection as the cause of congenital cardiac anomalies. Amer. F. med. Sci., 186, 705. 
Gallavardin, L. (1909). Du rétrécissement aortique non rhumatismal des jeunes sujets, et de son analogie avec le rétrécissement mitral de Duroziez. Lyon méd., 112, 189.

- (1921). Le rétrécissement aortique non rhumatismal des jeunes sujets. Presse méd., 29, 224.

- (1936). Le rétrécissement aortique non rhumatismal (d'après 50 observations personelles). $f$. Méd. Lyon, $17,593$.

Gibbs, A. J. (1935). Aortic stenosis: its etiology and morbid anatomy. Guy's Hosp. Rep., 85, 275.

Gordon, W. (1922). A case of non-rheumatic aortic stenosis in a young subject. Brit. med. f., 1, 836.

Grishman, A., Steinberg, M. F., and Sussman, M. (1947). Congenital aortic and subaortic stenosis with associated anomalies of the aorta. Med. Clin. N. Amer., p. 543.

Hall, E. M., and Anderșon, L. R. (1943). The incidence of rheumatic stigmas in hearts which are usually considered nonrheumatic. Amer. Heart f., 25, 64.

Herrick, J. B. (1933). In discussion after Levine's paper. 7. Amer. med. Ass., 101, 438.

Hohn, A. R., Van Praagh, Stella, Moore, A. A. D., Vlad, P., and Lambert, E. C. (1965). Aortic stenosis. Circulation, 32, Suppl. III, p. 4.

Karsner, H. T., and Koletsky, S. (1947). Calcific Disease of the Aortic Valve. J. B. Lippincott, Philadelphia and London.

Levine, S. A. (1933). The systolic murmur: its clinical significance. f. Amer. med. Ass., 101, 436.

- (1945). Clinical Heart Disease, 3rd ed., p. 52. W. B. Saunders, Philadelphia and London.

Lewis, T. (1933). Material relating to coarctation of the aorta of the adult type. Heart, 16, 205.

-, and Grant, R. T. (1923). Observations relating to subacute infective endocarditis. Heart, 10, 21.

Lloyd (1847). Aortic valvular disease. Trans. path. soc. Lond. 1846-48, 1, 40.

McGinn, S., and White, P. D. (1934). Clinical observations on aortic stenosis. Amer. F. med. Sci., 188, 1.

Margolis, H. M., Ziellessen, F. O., and Barnes, A. R. (1931). Calcareous aortic valvular disease. Amer. Heart $\mathcal{F}$., 6, 349.
Mitchell, A. M., Sackett, C. H., Hunzicker, W. J., and Levine, S. A. (1954). The clinical features of aortic stenosis. Amer. Heart F., 48, 684.

Oleson, K. H., and Warburg, E. (1958). Isolated aortic stenosis: the late prognosis. Acta med. scand., 160, 437.

Osler, W. (1886). The bicuspid condition of the aortic valves. Trans. Ass. Amer. Physcns, 1, 185.

Paget, J. (1844). On obstructions of the branches of the pulmonary artery. Med.-chir. Trans., 27, 162.

Peacock, T. B. (1853). On malformations of the aortic valves as a cause of disease. A paper from the Monthly Journal of Medical Science bound in the Royal Society of Medicine, London, as Peacock on the Brain, Heart, etc.

- (1865). On Some of the Causes and Effects of Valvular Disease of the Heart: Croonian Lectures. Churchill, London.

- (1868). Very great contraction of the aortic orifice from disease of the valves. Trans. path. Soc. Lond., 19, 163.

Pomerance, A. (1967). Ageing changes in human heart valves. Brit. Heart f., 29, 222.

Pyke, D., and Symons, C. (1951). Calcification of the aortic valve and of the coronary arteries. Brit. Heart f., $13,355$.

Simpson, K. (1947). Pathology of sudden death. Lancet, 2, 745.

Smith, D. E., and Matthews, M. B. (1955). Aortic valvular stenosis with coarctation of the aorta; with special reference to the development of aortic stenosis upon congenital bicuspid valves. Brit. Heart f., 17, 198.

Wauchope, G. M. (1928). The clinical importance of variations in the number of cusps forming the aortic and pulmonary valves. Quart. F. Med., 21, 383.

White, P. D. (1951). Heart Disease, 4th ed., p. 692. Macmillan, New York.

Wilks, S., and Moxon, W. (1875). Lectures on Pathological Anatomy, 2nd ed., p. 135. J. and A. Churchill, London.

Willius, F. A. (1927). A clinical study of aortic stenosis. Proc. Mayo Clin., 2, 123.

Wood, P. (1956). Diseases of the Heart and Circulation, 2nd ed. Eyre and Spottiswoode, London.

- (1958). Aortic stenosis. Amer. F. Cardiol., 1, 553. 